\title{
カーボン長繊維強化型窒化ケイ素の衝撃三点曲げ試験 ${ }^{\dagger}$
}

\author{
小川欽也* 倉 石 晃 ${ }^{* *}$ \\ 西田俊彦*** 杉山文子*

\section{Impact Three-Point Bending Test of a Continuous Carbon Fiber-Reinforced Silicon Nitride}

by

\author{
Kinya Ogawa*, Akira Kuraishi**, Toshihiko NishidA*** \\ and Fumiko Sugryama*
}

\begin{abstract}
Bending strength of a continuous carbon fiber-reinforced silicon nitride was experimentally investigated at high rate of strain by a split Hopkinson pressure bar method. Ramped incident waves were applied to the specimen to obtain a smooth load-deflection curve without high frequency oscillations. Acoustic emission during impact deformation was successfully detected as well as quasi-static deformation and the evidence of micro-cracking in the relatively early stage of high velocity deformation was confirmed. The dependences of strength and fracture morphology on fiber orientation and specimen size were clarified and their rate dependences were also identified. Tensile strength was found to be almost independent of deformation rate, while shear strength along fiber direction was significantly increased with rise of strain rate. Fiber bridging over a fracture surface affected shear strength and provided a reasonable explanation of experimental results.
\end{abstract}

Key words : Impact bending, Ceramic composite, Carbon fiber, Silicon nitride, Hopkinson bar, Ramped wave, Fracture, Strain rate effect

\section{1 緒}

長緎維強化型セラミックスは比較的軽量で, 耐熱性や 破壞抵抗性にもすぐれた特長を発揮するので, 将来の航 空宇宙機器や高速輸送体用の構造材料として有望視され, 種々の力学的環境下での強度やじん性の評価が必要と なっている. セラミックス系ぜい性材料の引張り試験は 一般に困難なため, 引張強度の評価には簡便な曲げ試験 が賞用され，ファインセラミックスに対しては準静的な 曲げ強さ試験方法（JIS R 1601）が規定されている. しかし本研究で取り上げた長纎維一方向強化セラミック 又等のように, 繊維配向方向の引張強度に較べて層間せ ん断強度が著しく低い材料では, 曲げ試験で引張強度を 簡便に評価することは困難であり, せん断や圧縮破壊強 度の方位異方性を考慮した適切な試験片形状・寸法と負 荷方法の選択が必要となる。

またこれらの材料が動的部材として有望視されている ことを考虑すると, 衝撃強度の評価にも着手することが 望まれる. セラミックス系材料の衝撃蚛度評価について は, 計装化シャルピー試験による曲げ試験が主として行 われてきたが, 試験機内での弾性応力波の多重反射や, 急激な負荷による慣性力効果等により，極めて低い衝撃
速度域を除けば，強度を正確に評価することは困難であ る.このような点を考慮して, 著者らは衝撃試験法とし て最も信頼性の高いと言われるホプキンソン棒法に，立 ち上がりの緩やかなランプ波を導入することで, 瀻維強 化プラスチック試験片の高周波振動を抑えた正確な三点 曲げの荷重一たわみ関係が得られることを示してきた。. 山内ら゙, および日下らうも同様な手法を踏襲し, 衝撃荷重 下での破壊じん性を的確に測定できることを報告してい る.

本研究では，上述の改良型ホプキンソン棒法を用いた 衝撃三点曲げ試験により, 長瀻維一方向強化型セラミッ ク複合材の曲げ強度測定を行い,この試験方法がセラ ミックス系の複合材の衝撃破壊試験にも有効であること を確認すると共に，その際の試験片形状・寸法が破壊形 態に与える影響を調べた．さらに衝撃变形から破壊に至 るまでの $\mathrm{AE}$ を捉え，破壊形態の内容を㵶維の引張破 壊と㵶維積層面間のせん断破壊挙動を考慮しながら整理 することを試みた。そして得られた衝撃曲げ試駼結果を 準静的曲げ試験結果と対応させながら，破壊強度に及ほ す負荷速度の影響についても言及した.

\section{2 試験材料および試験方法}

\footnotetext{
$\dagger \quad$ 原稿受理 平成 7 年 5 月24日 Received May 24, 1995

* 正 会 員 京都大学工学部航空宇宙工学研究科 ₹606-01 京都市左京区吉田本町, Div. of Aero. \& Astro., Kyoto Univ., Sakyo-ku, Kyoto, 606 $-01$

** 京都大学工学部学生 \%606-01 京都市左京区吉田本町, Student, Dept. of Aero. Eng., Kyoto Univ., Sakyo-ku, Kyoto, 606-01

*** 正 会 員 京都工芸繊維大学工芸学部物質工学科 $\mathbf{T} 606$ 京都市左京区松ヶ崎御所海道町, Dept. of Mat. Sci., Kyoto Inst. of Tech., Sakyo-ku, Kyoto, 606
} 
供試材はノリタケカンパニー社製のカーボン長繊維一 方向強化窒化ケイ素（繊維含有率 $50 \%$ ）であり，プリ プレグを積層後，ホットプレスにより焼結された。Fig. 1 に試験片の形状と負荷方向を示し, Table I に試験片 幅（B）および高さ（ $H$ ）の標準值を示す．曲げ方向は ホットプレス方向（以下, 試験片 I と表示）と, これに 直角方向（以下，試験片 II と表示）の二種類であり，い ずれの場合もスパン方向に繊維配向方向を一致させた.

Fig. 2 にはホプキンソン棒型衝撃三点曲げ試験装置の 構成を示す. 直径 $10 \mathrm{~mm}$ の入力棒（ステンレス鋼）先 端は楔状に加工し, 曲率半径 $4 \mathrm{~mm}$ の負荷点とした. 出 力管には直径 $8 \mathrm{~mm}$, 肉厚 $0.5 \mathrm{~mm}$ の二本の銅管を用い, 先端を閉じて, 曲率半径 $4 \mathrm{~mm}$ の支持点とした. スパン （L）は $32 \mathrm{~mm}$ である. 入力棒と出力管とは細いゴムで 結ばれ，荷重点と支持点を介して極く小さな力で試験片 を保持した. 入力棒の打ち出し棒側の端面にはバッファ 一として円柱状の金属亜鉛を置き, その塑性変形によっ て生じる立ち上がりの緩やかな入射波（ランプ波）を試 験片に入射した.

入射波と反射波を分離して観測するため，入力棒には 二ヶ所にひずみゲージを貼付した．透過応力波の振幅は 小さいため, 出力管には半導体ひずみゲージを用いた.

入力棒, 出力管ならびに試験片に貼付したひずみゲー ジからの出力はホイートストンブリッジ，プリアンプ （応答周波数 $1 \mathrm{MHz}$ ) を介して 12 チャンネルのストレ ージスコープ（最高サンプリング速度 20 address $/ \mu \mathrm{s}$, 縦軸分解能 10 bit）に取込み, フロッピーディスクに記 録保存した.

Table I. Dimensions of specimens (mm).

\begin{tabular}{c|c|c}
\hline Specimen & Width $B$ & Height $H$ \\
\hline I & 4 & $3,2,1.5,1$ \\
\hline II & 3 & $4,3,2,1.5,1$ \\
\hline
\end{tabular}

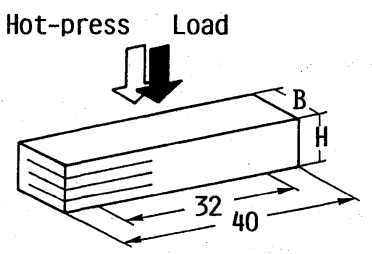

Specimen 1

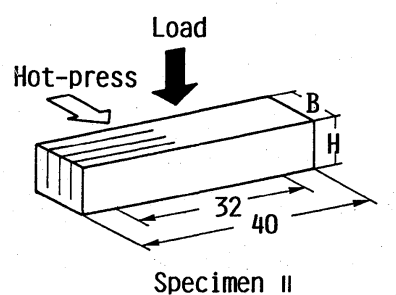

Fig. 1. Specimen geometry and loading direction.

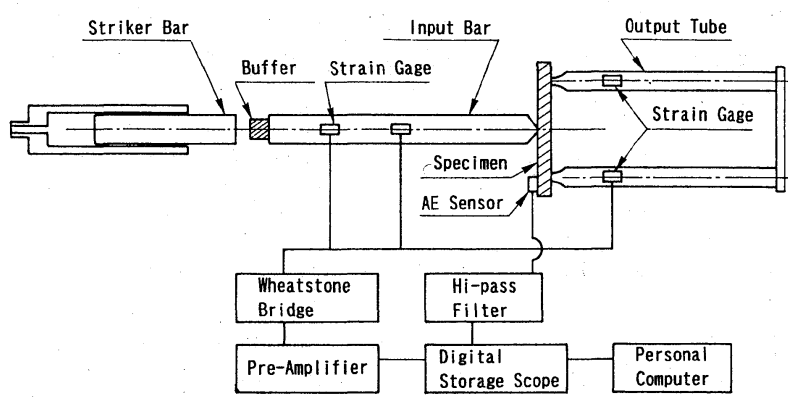

Fig. 2. Impact three-point bending test apparatus and measuring circuit.

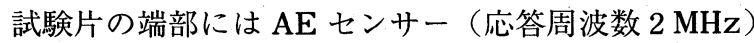
を接着し，ハイパスフィルター（カットオフ周波数 110 $\mathrm{kHz}$ )を通じた後，電圧出力を同様にストレージス コープに記録した。試験温度は室温 $\left(13 \sim 15^{\circ} \mathrm{C}\right)$ であ る.

\section{3 試験結果および考察}

\section{$3 \cdot 1$ 入射波, 反射波および透過波}

Fig. 3 には，バッファーを用いないで得られる立ち上 がりの鋭い矩形波と，金属亜鉛のバッファーを用いて得 られるランプ波を試験片に入射した場合のそれぞれにつ いて，得られた反射波怙よび透過波を示す。

立ち上がりの鋭い矩形波を入射した場合には，シャル ピー試験で観測されるのと同様に，透過波に大きな振動 が現れる。このため，準静的試験の場合には，荷重とた わみの関係に非線形性が現れ始める荷重値を比較的容易 に特定でき，微視的な破壊挙動を推定することができた が，ここに示す衝撃試験の場合には，これを予測するこ とは極めて困難である．また，破壊強度を評価するため の最高応力値を精度良く定めることも困難となる.

これに対して，立ち上がりの緩やかなランプ波の場合 には，透過波は滑らかに増加し，非線形性が現れ始める 荷重值および最高值を容易に求めることができる．なお， 入射応力波に対して透過応力波は十分の一程度の大きさ であるため，入射応力波の微小な乱れも透過応力波に大 きな影響を与える．従って，滑らかなランプ波を与える ことがこの試験法においては極めて重要である.

矩形波, ランプ波のいずれの場合も，反射波は 1 次元 弾性波理論で予測される時刻にひずみゲージの位置に到 達したが，矩形波を入射した場合の透過波は約 $30 \mu \mathrm{s}$, ランプ波を入射した場合の透過波は約 $10 \mu \mathrm{s}$ ，理論的に 予測された時刻より遅れてひずみゲージの位置に到達し

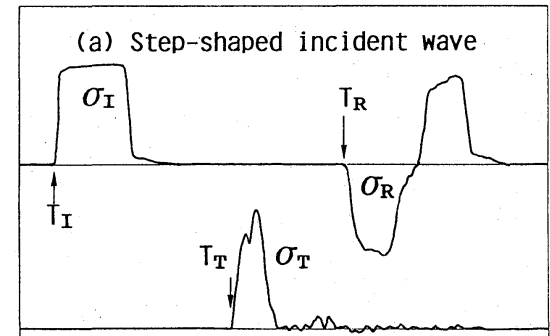

(b) Ramped incident wave

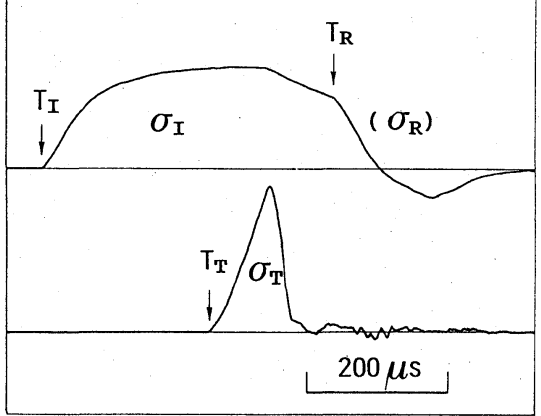

Fig. 3. Stress waves for step-shaped (above) and ramped incident waves (below). Incident, reflected, and transmitted waves start at $T_{I}, T_{R}$, and $T_{T}$, respectively. 
た. 試験片の保持方法から考えて負荷点, あるいは支持 点と試験片とに最初から間隙はない，また，後に詳しく 示すが, 試験片端部に付けた $\mathrm{AE}$ センサーは負荷点に 入射波が到達してから約 $4 \mu \mathrm{s}$ 経過後に応答し始めてお り，その時刻に応力波が試験片の端部に到達しているこ とを示している.

以上の点より，透過波の遅れの大半は衝撃力により試 験片が支持点から浮き上がり，このため出力管への弾性 波の到達が遅れた結果であると考えられる．従って，ラ ンプ入射波では試験片の支持点よりの浮き上がりが抑制 されていることが分かり，これが試験片と支持点，ある いは負荷点との再衝突による高周波振動の発生を抑えて いると推定できる.

入力棒中を伝ぱする入射応力波を $\sigma_{I}$, 反射応力波を $\sigma_{R}$, 出力管を伝ぱする透過応力波を $\sigma_{T}$ とし, $A_{1}, A_{2}$ を それぞれ入力棒と, 二本の出力管の断面積とすると, 負 荷点および支持点での荷重 $\left(P_{1}, P_{2}\right)$, 速度 $\left(V_{1}, V_{2}\right)$ は次式で与えられる。

$$
\begin{array}{cl}
P_{1}=A_{1}\left(\sigma_{I}+\sigma_{R}\right), & P_{2}=A_{2} \sigma_{T} \\
V_{1}=\left(\sigma_{I}-\sigma_{R}\right) / \rho_{I} c_{I}, & V_{2}=\sigma_{T} / \rho_{T} c_{T}
\end{array}
$$

これより，たわみ速度 $(\dot{\delta})$ は次式で表せる.

$$
\dot{\delta}=\left(\sigma_{I}-\sigma_{R}\right) / \rho_{I} c_{I}-\sigma_{T} / \rho_{T} c_{T}
$$

ここに, $\rho_{I} c_{I}, \rho_{T} c_{T}$ はそれぞれ入力棒, 出力管の音響イ ンピーダンスである.

ランプ波を与えた場合には, 変形の初期（約 $20 \mu \mathrm{s}$ 以内）を除けば，負荷点での荷重と支持点での荷重がほ ぼ同じであることを既に FRP について確認している. 従って，透過波のみを用いて試験片の荷重 $(P)$ を，ま た，入射波 $\left(\sigma_{I}\right)$ と透過波 $\left(\sigma_{T}\right)$ とを用いてたわみ速度 $(\dot{\delta})$, たわみ $(\delta)$ を以下のように算出できる.

$$
\begin{aligned}
P= & A_{1} \cdot \sigma_{T} \\
\dot{\delta}= & 2 \sigma_{I} / \rho_{I} c_{I} \\
& \quad-\sigma_{T} / \rho_{T} c_{T}\left(\left(A_{2} / A_{1}\right)\left(\rho_{T} c_{T} / \rho_{I} c_{I}\right)+1\right) \\
\delta= & \int \dot{\delta} d t
\end{aligned}
$$

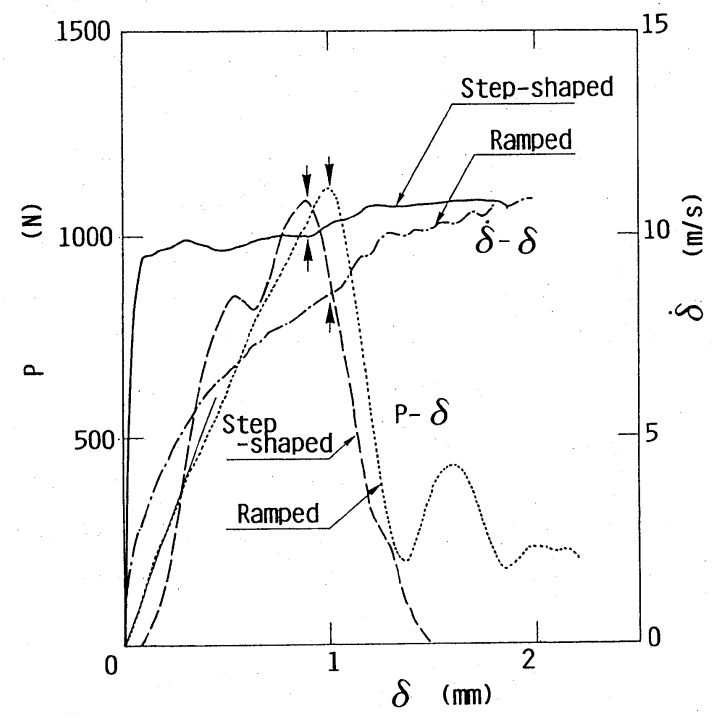

Fig. 4. Load and deflection velocity during deformation for the cases of step-shaped and ramped incident waves.
Fig. 4 には，式(5)，(6)よりそれぞれ求まるたわみ速度 とたわみの関係を，矩形波とランプ波を入射した場合に ついて示す．矩形波の場合には，変形初期よりたわみ速 度が急激に増加し，ほぼ一定のたわみ速度に達した状態 で試験片が破壊する。一方，ランプ波の場合には，初期 のたわみ速度は低いが, この状態で生じるたわみも小さ い:たわみ速度が上昇すると，これに応じてたわみも急 激に増加するため, 変形が進んだ時点では, 十分高い変 形速度が達成される. 即ち, ランプ波を用いれば変形初 期の振動を抑制し, 十分な高変形速度での破壊強度を的 確に測定できることが分かる.

応力波より式(5)，(6)および，後に示す式(9)を用いて求 めた試験片中央の引張側でのひずみは, 試験片に貼付し たゲージより求めた值とほぼ一致することを先に報告し た. 従って, 衝撃試験での曲げモードは準静的試験の場 合と同じであるとして良く，準静的試験での荷重一たわ み関係と比較して強度に及ぼす变形速度の影響を調べる ことができる.

\section{$3 \cdot 2$ 荷重一たわみ関係}

Fig. 5 には，荷重-たわみ関係より求めた試験片中央 最外層での引張応力 $(\sigma)$ とひずみ $(\varepsilon)$ の関係を, 試 験片高さ $(H)$ をパラメータにして示す.ここで， $\sigma$, $\varepsilon$ は三点曲げの初等理論により次式で求めた.

$$
\begin{aligned}
\sigma & =3 P \cdot L /\left(2 B \cdot H^{2}\right) \\
\tau & =3 P /(4 B \cdot H) \\
\varepsilon & =6 \delta \cdot H / L^{2}
\end{aligned}
$$

ただし， $P$ は荷重， $\delta$ は試験片中央でのたわみ， $\tau$ は中 立面内のせん断応力, である.

試験片 I，II のいずれの場合も， $\sigma^{-} \varepsilon$ 関係は応力值 200 400 MPa より弾性的な直線関係から外れはじめ, 長い非弾性挙動を示した後，最高応力值を経て破壊に至 る. $H$ が小さい場合には，破壊までのたわみが大きく なり，大たわみの影響で弾性域においても荷重一たわみ 関係が非線形となることが考えられるが， $\delta / L \leqq 0.06$ ではその影響はないことが知られている. 従って, ここ での非線形挙動は材料の変形そのものに起因していると 考えられる。このように, $\sigma-\varepsilon$ 関係は非弾性挙動を示し た後, 最高応力值に達するため, 破壊応力を弾性応力值 として評価することには若干の問題があるが, ここでは, 非弾性的変形量が大きくないとして，式(7)あるいは式(8) を用いて評価する。

\section{$3 \cdot 3 \mathrm{AE}$ 計測}

Fig. 6 にはランプ入射波を負荷した時に得られた $\mathrm{AE}$ センサーからの電圧出力を支持点での荷重-時間関係と 対応させて示す.

まず，入射応力波が試験片の負荷点に到達してから約 $4 \mu \mathrm{sec}$ 経過した時刻（ $\left.T_{1}\right)$ において，試験片の端部が 加速され始め, $\mathrm{AE}$ センサーは加速度センサーとして応 答を開始するが，この時点では，高周波の $\mathrm{AE}$ は認め られない. $T_{1}$ より約 $6 \mu \mathrm{sec}$ 経過した時刻 $\left(T_{2}\right)$ にお いて，支持点での荷重が増加し始め，これが最高荷重の $20 \%$ 程度に達した時点 $\left(T_{3}\right)$ より， $\mathrm{AE}$ が現れる. 

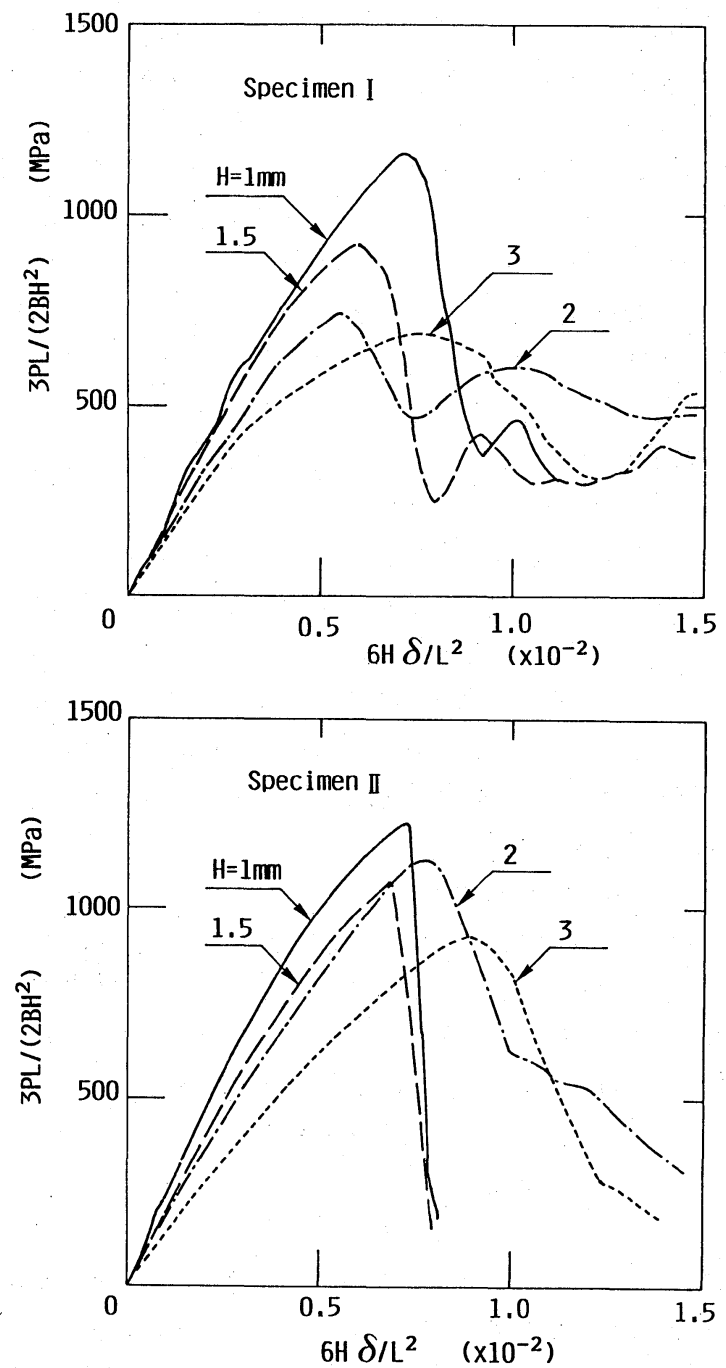

Fig. 5. Dynamic stress-strain curves for various height of specimen I (above), and specimen II (below).

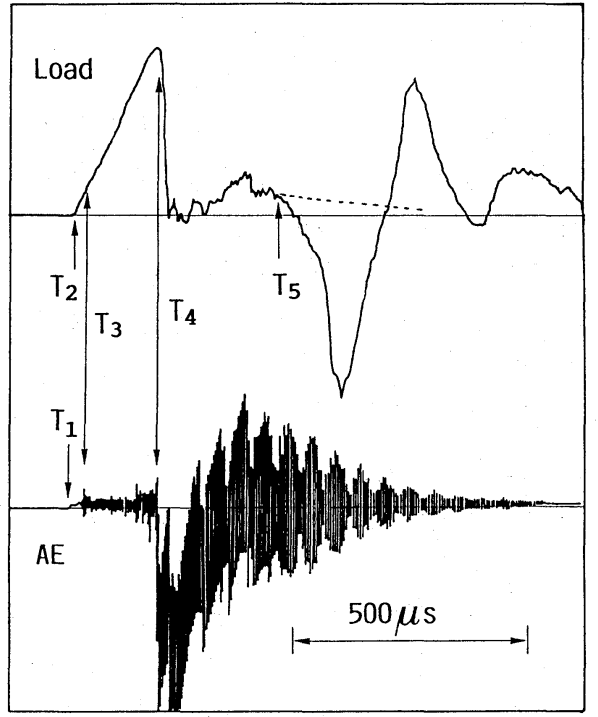

Fig. 6. Acoustic emission (AE) during impact deformation by ramped incident wave (specimen II, $H=4 \mathrm{~mm}$ ).
Fig. 5 を参照すると, この程度の荷重值より荷重一たわ み関係が非線形性を示し始めることが分かる. これ以後, ほぼ一定の振幅の $\mathrm{AE}$ が継続しているが，このような $\mathrm{AE}$ はマトリックス中に発生する微小き裂，あるいはマ トリックスと瀻維との界面で起こるはく離によるものと 推定でき，準静的試験の場合と同様に，衝撃試験におい ても, 変形のかなり初期段階からはく離等が生じている ことが確認できる.

最高荷重点近傍では, AE の振幅が増加し, 巨視的な き裂が発生したものと推定できる.これ以後, 荷重が急 激に低下し始める時点 $\left(T_{4}\right)$ では, $\mathrm{AE}$ センサーの出力 は大きく変化し, 試験片は再び急激な加速度運動を開始 したことが分かるが，これは，試験片中を巨視的なき裂 が伝ぱしたことによると推定できる. 荷重の低下後も,

$\mathrm{AE}$ センサーの出力は振動を伴いながら徐々に減衰して いるが，かなり長時間にわたって持続しており，破断過 程が継続していることを示している.（なお，時刻 $\left(T_{5}\right)$ 以後の破線で示した荷重は, 出力管の自由端から 反射される応力波を考慮して求めた。）ここに示した試 験片 II の $H=4 \mathrm{~mm}$ の場合には，引張破壊とせん断破壊 とが共に進行し, 後に示すように破面は非常にけば立っ ている.これは, 試験片が瞬時には切断されず, 繊維の 引き抜けやはく離が持続しながら最終的な破断へと進行 したことを明瞭に示している，また，このような破壊過 程において, 試験片には顕著な振動が生じており, 荷重 低下過程での応力状態や曲げモードが準静的な変形の場 合とは異なっている可能性がある. 従って, 破壊の全過 程について吸収エネルギーの評価を行なうにあたっては, これらの点を十分考慮しながら検討することが今後必要 であろう。

\section{$3 \cdot 4$ 強度の異方性と変形速度依存性}

Fig. 7 には, 最大荷重值で最外層に生じる引張応力 $(\sigma)$ および中立面上でのせん断応力 $(\tau)$ と試験片高さ (H) との関係を示す.

いま, 一定の引張破壊応力（ $\sigma_{c} ）$ あるいはせん断破壞 応力 $\left(\tau_{c}\right)$ で破壊が起こるとする. また，破壊時には最 高荷重を示し，その際の応力は式(7)および式(8)で与えら れるとすれば，Hの大きい場合にはせん断破壊が起こ り $\tau_{c}$ が, $H$ の小さい場合には引張破壊が生じて $\sigma_{c}$ が, それぞれ得られるはずである，先に報告した準静的曲げ 試験では，試験片 I の $H=1 \mathrm{~mm}$ の場合にはせん断破壊 の様相が若干認められたが，今回の衝撃曲げ試験では明 瞭に引張破壊し， $\sigma_{C}=1.2 \sim 1.3 \times 10^{3} \mathrm{MPa}$ が得られた。

また, $H \geqq 2 \mathrm{~mm}$ の場合にはせん断破壊が生じ, $\tau_{c}=30$ $\mathrm{MPa}$ が得られた. 一方, 試験片 II では, $H \leqq 2.0 \mathrm{~mm}$ の 場合に引張破壊し， $\sigma_{c}=1.2 \sim 1.3 \times 10^{3} \mathrm{MPa}$ が得られ, $H \geqq 2.5 \mathrm{~mm}$ の場合にはせん断破壊し， $\tau_{c}=50 \mathrm{MPa}$ が得 られた。

準静的曲げ試験での引張破壊強度は試験片 II について $1.1 \times 10^{3} \mathrm{MPa}$ 程度であるから，これより，引張破壊強 度は変形速度にほとんど依存しないことが分かる．本複 合材の強化繊維であるカーボン繊維の破壊強度について 

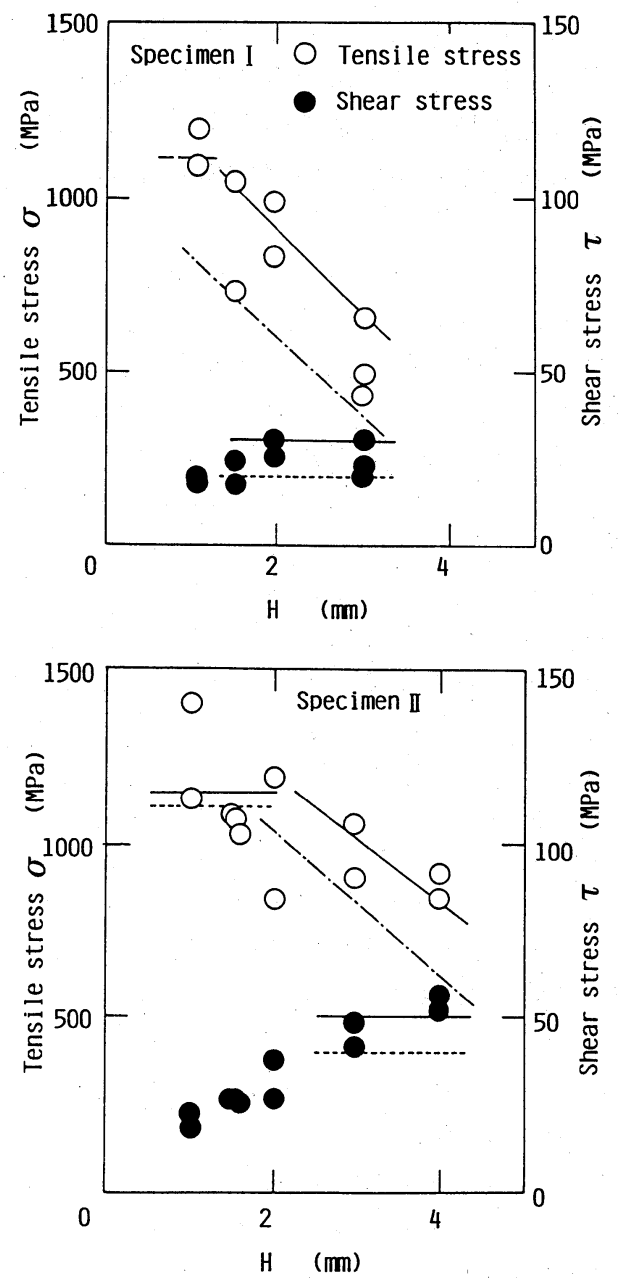

Fig. 7. Relation between strength and specimen height for specimen I (above) and specimen II (below).

は, CFRP の破壊強度が変形速度にほとんど依存しな いことから, 変形速度にほとんど依存しないと推定され る.

準静的曲げ試験と同様に, 衝撃曲げ試験においても比 較的変形の初期段階から $\mathrm{AE}$ が観察されることより, どちらの場合においても, 最高荷重点以前にマトリック スには微細なき裂が生じ, 繊維とマトリックスとの界面 でのはく離も進行していると推定できる. 従って, 破壊 時にはカーボン繊維が大部分の荷重を負担していると考 えられ, このことが, 本複合材の引張破壊強度が変形速 度にほとんど依存しなかった主な原因であると理解でき る.

一方, $H$ が大きい領域で現れるせん断破壊強度は変 形速度に著しく依存し, いずれの試験片においても衝撃 試験では，準静的試験の場合（図中に破線で示す）の $50 \%$ 程度の強度の上昇が見られる. 繊維とマトリック スの界面でのはく離機構の速度依存性については未だに 明確ではないが, 例えばカーボン繊維で強化したガラス において, 破壊速度を遅くすると繊維の引抜き長さが長 くなる結果が得られていることなどを考慮すると, 衝撃 試験においてはせん断破壊挙動が抑制されることが考え
られる。 また, 本複合材の試験片 IIに生じるせん断破壊 の速度依存性に関しては，既に圧縮試験においてその強 度が変形速度の増加によって上昇することを実験的に明 らかにしており，ここでの結果と定性的に対応している。

このように衝撃試験ではせん断強度が変形速度の増加 によって上昇するため, 引張破壊が生じる $H / L$ 比が相 対的に大きくなる. この結果, 準静的試験では困難で あった試験片 Iにおいても，衝撃試験においては同じ $H$ に対して引張破壊強度を測定できる可能性がある.

次に, 試験片 I と II の場合のせん断強度について比較 してみると, 先に報告したように, プリプレグの積層面 (ホットプレス方向と垂直な面) 内では繊維が交差して おり，積層面に垂直な面でのせん断では繊維のブリッジ ング効果が一部現れる，従って，衝撃試験の場合におい ても，積層面に垂直な面でのせん断破壊応力が積層面で のせん断破壊応力に比べて高くなることが理解できる.

強度の変形速度依存性については，両者の間に顕著な 違いは認められず，ブリッジング効果は変形速度にあま り依存しないことが分かる．これは，既述したように， カーボン繊維の強度が変形速度によってほとんど変化し ないことによるとして理解できる。

\section{$\mathbf{3} \cdot \mathbf{5}$ 破壊様式}

Fig. 8 には衝撃試験で生じた破壊の状況を示す.試験 片の破壊状況は試験片 I，IIによって異なると共に, 試 験片高さ（H）によっても異なる. まず試験片 I の場合, $H$ が大きい時には, 積層間のはく離によって試験片が 薄片状に破壊すると共に, 負荷点直下から引張側へ繊維 に垂直に進行したと思われるき裂によって切断する，H が小さい場合には, 積層間のはく離は生じないが，やは り負荷点で切断する. この場合のき裂は, 負荷点の反対 側である引張側から負荷点へ向かって緎維に垂直に進行 し，明らかな引張破壊の様相を呈する.

一方, 試験片 II では $H$ の大きい場合, 負荷点直下か ら支持点に向かって斜めにき裂が伝ぱする．き裂周辺に は繊維に沿ってのはく離が生じているのが認められ, 引 張破壊とせん断破壊とが共に進行しているのが分かる. また，き裂が最終的に通過する試験片の引張側では繊維 が曲げ方向に扇形に押し広げられ，広い範囲にわたって はく離している．このことは，リガメント部分が破断す る過程がかなり長時間にわたって持続することを示して おり，先に $\mathrm{AE}$ 測定について述べた事実と良く対応し ている.なお，準静的曲げ試験の場合と同様に，衝撃曲 げ試験の場合にも，き裂が圧縮側から引張側へ伝ぱする ことは試験片の表裏に貼付したひずみゲージの応答を調 ベることにより既に明らかにしている。

$H$ の小さい場合には, 負荷点近傍の圧縮域に若干の はく離および繊維のバックリングが認められるが，破面 では繊維が長く引き抜けており，負荷点の反対側である 引張側から負荷点へ向かって瀻維に垂㨁に進行する引張 破壊が生じていることが分かる.

以上, これらの結果を, 準静的試験での結果と比較す ると, いずれの破壊の場合にも, 破面の形態に及ぼす変 


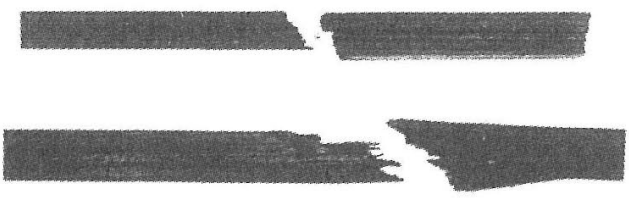

(a) Optical micrographs of fractured specimens I (above, $H=3 \mathrm{~mm}$ ) and II (below, $H=4 \mathrm{~mm}$ ).
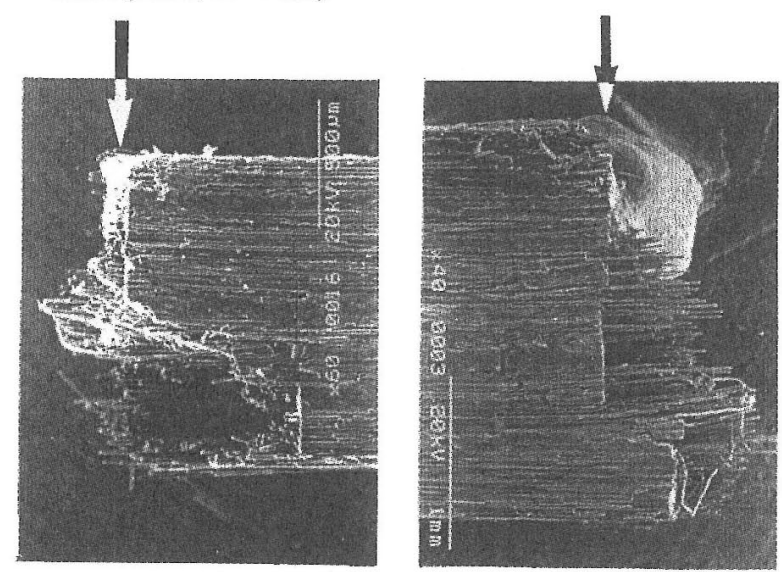

(b) SEM micrographs of fractured specimens I (left, $H=1.5 \mathrm{~mm}$ ) and II (right, $H=2 \mathrm{~mm}$ ).

Fig. 8. Appearance of fractured specimens.

形速度の影響は顕著には認められない。

$$
4 \text { 結 論 }
$$

カーボン長繊維一方向强化窒化ケイ素セラミックスの 衝揧三点曲げ試験を行ない，繊維配向方向の強度につい て次の結果を得た。

（1）立ち上がりの緩やかなランプ入射波を負荷するこ とによって, 高周波振動のない滑らかな出力波形を得る ことができ，破壊強度を正確に求めることができる。

(2) 繊維配向方向のせん断強度は引張強度に比べて著 しく低く，また，纎維のブリッジングの効果を強く受け る.

（3）せん断破壞強度は繊維とマトリックスとの界面で のはく離強度に主に支配され, 変形速度の増加と共に上 昇する。一方, 引張破壊強度は主に強化瀻維であるカー ボン纎維の破壊強度に支配され，変形速度にほとんど依 存しない。この結果, 試験片高さが準静的試験の場合よ
り大きい試験片に扔いても，せん断破偯を生じることな く, 衝撃引張破壊強度を求めることができる。

（4）せん断破壞，引張破壞のいずれに打いても，破面 の形態に及ぼす恋形速度の影響は認められない。

\section{参考文 献}

1) 小川欽也，倉石 晃，西田俊彦，材料，44，1074（1995）.

2）小川欽也，西田俊彦，倉石 晃，杉山文子，材料，44, 1157 (1995).

3) R. A. Wullart, ASTM STP-466, 148 (1970).

4) S. Venzi, A. H. Priest and M. J. May, ASTM STP-466, 165 (1970).

5) H. J. Saxton, D. R. Ireland and W. L. Server, ASTM STP $-617,50$ (1977).

6) 小川欽也，東田文子，強化プラスチックス，36，123 (1990).

7 ）東田文子, 小川欽也，材料，39，1462（1990）。

8 ）山内良昭, 黒川知明, 日下貴之, 材料, 42, 1445 (1993).

9) 日下貴之, 黒川知明, 山内良昭, 材料, 43，445 (1994).

10）岩田美佐男，粉体㧍よび粉末治金，37，1108（1990）.

11) F. E. Hauser, J. A. Simons and J. E. Dorn, Response of Materials to High Velocity of Deformation, 93 (1960) N. Y. Wiley.

12）杉山文子, 小川欽也, 西田俊彦, 日本機械学会第72期通常 総会講演会講演論文集（II）, p. 56 （1995）.

13）植村益次，日本複合材料学会誌，7，74 (1981).

14) H.C. Cao, E. Bischoff, O. Sbaizero, M. Ruhle, A. G. Evans, D. B. Marshall and J. J. Brennan, J. Am. Ceram. Soc., 73, 1691 (1990).

15) R. T. Bhatt, "Whisker-and Fiber-Toughened Ceramics", Proc. Inter. Conf., p. 199 (1988).

16) J. Harding, K. Saka and M. E. C. Taylor, Impact Loading and Dynamic Behaviour of Materials, 1, 515 (1988).

17) J. Harding and L. M. Welsh, J. Mat. Sci., 18, 1810 (1983).

18) L. M. Welsh and J. Harding, Mechanical Properties at High Rates of Strain, 1984, Inst. Phys. Conf. Ser. No. 70, 343 (1984).

19) D. C. Phillips, J. Mat. Sci., 7, 1175 (1972).

20）小川㰸也, 西田俊彦, 杉山文子, 岩田美佐男, 日本機械学 会機械力学・計測制御講演論文集(A), p. 141 (1992). 